2019 Global Fashion Management Conference at Paris Proceedings: 589-593 (July 2019) https://doi.org/10.15444/GFMC2019.06.01.02

\title{
DO HEDONIC REWARDS AT ONLINE COMMUNITIES AFFECT CONSUMER-FASHION BRAND ENGAGEMENT? A PLS APPROACH
}

\author{
Ricardo Godinho Bilro, Instituto Universitário de Lisboa (ISCTE-IUL) and Business \\ Research Unit (BRU/IUL), Portugal ${ }^{1}$ \\ Sandra Maria Correia Loureiro, Instituto Universitário de Lisboa (ISCTE-IUL) and \\ Business Research Unit (BRU/IUL), Portugal ${ }^{2}$ \\ Maria Gonçalves Cabaço, Instituto Universitário de Lisboa (ISCTE-IUL) ), Portugal
}

\begin{abstract}
\section{Introduction}

Over the past few decades, consumers have become increasingly demanding, especially for the hundreds of brands that come up daily. Brands, on the other hand, must adapt constantly to these changes so that they become visible in a market as competitive as it is today (Zhang, Jiang, Shabbir, \& Du, 2015). Moreover, with a technologically more developed environment, consumers start to set aside paper journals, coffee conversations, or even phone calls, and start giving more importance to digital atmosphere in their daily lives.
\end{abstract}

With the arise of online brand communities as privileged platforms of interaction and information sharing between brands and consumers, these last ones cannot only access to up-to-date information about different brands, but also obtain several rewards such as hobbies, prizes, discounts, among others (Batra \& Keller, 2016). In addition, they can comment and talk with other consumers and/or fans of a particular brand, and share their experiences (Schamari \& Schaefers, 2015).

In this sense, the current research aims to explore the importance of the hedonic reward in the consumer engagement with online communities of fashion brands. Furthermore, we intend to analyses the role of hedonic versus utilitarian rewards that this type of online platforms can offer to consumers. This research gap arises from the need to further explore consumer's interaction motivations toward this type of platforms. To do so, we perform a quantitative study with data collected from consumers through an online questionnaire, with a sample of 367 respondents. With this research we intend to emphasize that fashion brands, and companies in general should deepen their presence in online communities, using hedonic rewards to promote consumer engagement, and consequently providing a continuous improvement of the brand itself. Thus, the main aim is to explore the relationship between different dimensions of Baldus et al. (2015) of online brand community engagement on subjective well-being and brand advocacy.

\section{Theoretical Background}

In the fashion industry, desire plays a key role in consumer-brand interactions. Rokeach (1973) states that desire is a value, a belief that guides actions and judgments. Perugini \& Bagozzi (2001) also argue that desires act as a stimulus to the transformation of motivations into actions / behaviors. According to Loureiro \& Panchapakesan (2017),

\footnotetext{
${ }^{1}$ bilro.ricardo@gmail.com

2 sandramloureiro@netcabo.pt
} 
desire results in action, as long as experience is important and involvement in that experience has meaning for the self (e.g. myself). This involvement can generate strong feelings and improve the five senses of the consumer about the experience. According to Blackwell et al. (2005), we can define involvement as an unobservable state of motivation and interest or as the degree of personal importance perceived by stimuli of a specific situation. The greater the level of consumer involvement, the longer the decision-making process, and the greater the consumer's attention to ads related to a particular product or brand. Minor \& Mowen (2003) report that the level of consumer involvement is important for understanding memory processes, for decision-making, attitude change and word-ofmouth (e.g. word-of-mouth communication).

Concerning hedonism, the interest in studying hedonic consumption arose due to the recognition by some authors, such as Babin et al. (1994), of its entertainment potential and emotional value, and that traditional explanations about product acquisition do not fully reflect the shopping experience. According to Alba \& Williams (2013), hedonism is about the consumption of products based mainly on emotional, multisensory aspects, and the desire to experience pleasure and happiness. Hirschman \& Holbrook (1982) pioneers of studies on the hedonic dimension of consumption - even suggests that consumption is driven by the consumer's enjoyment of certain products, essentially due to their aesthetic nature. For Babin \& Babin (2001), hedonism is focused on the achievement of immediate personal gratification in the shopping experience since it is connected to entertainment, it promotes emotional and social benefits to the consumer, which is, according to Batra \& Ahtola (1991) beyond the simple utility offered by the products.

Regarding engagement, this construct is associated with an expanded domain of Relational Marketing (Vivek, Beatty \& Morgan, 2012), and is linked to the level of physical, cognitive and emotional presence of the consumer in the relation that has to a particular brand or service (Patterson, Yu \& Ruyter, 2006). In fact, engagement undergoes enormous popularity among practitioners, and in the last few years we have faced a growing interest of this topic within the marketing literature. Authors have underlining that engagement can be a way to create value to companies (Brodie et al., 2011; Brodie et al., 2013), and to build an interactive relationship between a subject and a particular object, thus reflecting a motivational state of the subject (Hollebeek, 2011). Authors also understood engagement as a dynamic, iterative and value co-creating process, as well as predictive of consumer loyalty outcomes (Bowden, 2009; Brodie et al., 2011). The brand is usually seen as the object (Sprott, Czellar, \& Spangenberg, 2009; van Doorn et al., 2010) and the consumer as the subject of the relationship (Bowden, 2009). Vivek, Beatty, \& Morgan (2012) argue that engagement even enhances the understanding of consumer brand relationships and is a relevant component of relationship marketing. Finally, with regard to online communities, the concept of engagement is stated as an affective and cognitive commitment between consumers and brands, personified by their website or any other digital platform, in order for the brand to convey value to them (Mollen \& Wilson, 2010). Consumer engagement in an online community platform involves interactive virtual experiences between consumers and the brand and/or other members of the Community (Patterson et al., 2006).

\section{Methodology}

To perform this research, we decide to conduct a quantitative study through an online questionnaire. In this case, we opt to perform a questionnaire developed based on previous 
validated scales, with a total of 30 questions. This questionnaire was based on a 7-point Likert type scale based on Baldus et al. (2015) study, and comprises the following dimensions: Brand Passion, Connection, Hedonic Rewards, Utilitarian Rewards, Seeking Assistance, Up-to-date Information, Validation. Brand Advocacy and Subjective Wellbeing are measured based on Bhattacharya \& Sen (2003) and Etkin (2016), respectively. The sample consists on a total of 367 responses, which $54.2 \%$ of the participants were male. In terms of the respondents' age, a balance was sought in the dissemination of the questionnaire so that the sample was heterogeneous. In this sense, the majority population of this sample is comprised between 18 and 24 years old $(30.9 \%)$, followed by 25 to 34 years $(29 \%), 45$ to 54 years $(18 \%), 35$ to 44 years $(14.9 \%)$ and finally, with a lower percentage, 55-64 years old (5.8\%). These values are in line with the target population that participate in online communities. Partial least squares approach is employed to treat data.

\section{Preliminary findings}

PLS-SEM was employed to test the relationships. First the measured model was analyzed and all criteria of reliability, convergent and discriminant validity were assessed and confirmed. After that, the structural model reveals that Brand passion ( $\beta$ passion- $>$ hedonic $=0.199, \mathrm{t}=2.255 ; \beta$ passion- $>$ utilitarian $=0.299, \mathrm{t}=4.048)$, Seekingassistance $(\beta$ seeking- $>$ hedonic $=-0.159, \mathrm{t}=2.208 ; \beta$ seeking- $>$ utilitarian $=0.213, \mathrm{t}=3.095)$, and Validation ( $\beta$ validation- $>$ hedonic $=-0.309, \mathrm{t}=4.011$; $\beta$ validation- $>$ utilitarian $=0.258$, $\mathrm{t}=4$.134) have a positive and significant relationship with both Hedonic Rewards, Utilitarian Rewards. These last two construct have a significant effect on Brand Advocacy ( $\beta$ hedonic- $>$ advocacy $=-0.395, \mathrm{t}=7.707 ; \beta$ utilitarian- $>$ advocacy $=0.202, \mathrm{t}=4.378$ ) and Subjective Well-being ( $\beta$ hedonic->well-being $=-0.509, \mathrm{t}=11.527 ; \beta$ utilitarian- $>$ wellbeing $=0.209, \mathrm{t}=4.844)$. Regarding Connection, the association between connection and hedonic rewards is statistically significant $(\beta=0.207, \mathrm{p}<2.119)$, but not between Connection and utilitarian rewards $(\beta=-0.049, \mathrm{p}<0.557)$. In what concerns to Up-to-date information $(\beta=-0.203 \mathrm{p}<2.927)$, this is positively and significantly associated with Utilitarian rewards, but with Hedonic rewards $(\beta=-0.018 \mathrm{p}<0.286)$ is not significant.

Based on these preliminary findings, we may argue that the more engaged to a brand the consumer is, the more willing he/she has to participate and interact in the respective online brand community. Moreover, online brand communities allow consumers to have a better level of information about the brand to which they are engaged with, and they also recognize these types of platforms as a great way to keep up-to-date regarding that brand. Additionally, we may put in evidence that consumers use these platforms for the passion or admiration they have for certain brands. In fact, it is possible to assume from the results that the Brand passion dimension holds a relevant importance for the consumer-fashion brand engagement.

Regarding the hedonic/utilitarian rewards, we can highlight that consumers give more importance to hedonic rewards than to utility rewards, as it presents lower values than hedonic rewards. We are also able to underline that consumers tend to interact with these platforms to feel entertained. Still on hedonic rewards, we may put in evidence that consumers tend to interact with online brand communities to search for assistance (Seeking assistance), that is, consumers reveal the need to seek for help of others about a particular brand or related product while interacting on it. 


\section{Global Fashion Management Conference at Paris}

Keywords: hedonic rewards, online brand community engagement, brand advocacy, subjective well-being

Acknowledge: This work was supported by Fundação para a Ciência e a Tecnologia, grant UID/GES/00315/2019

\section{References}

Alba, J. W., \& Williams, E. F. (2013). Pleasure principles: A review of research on hedonic consumption. Journal of Consumer Psychology, 23(1), 2-18.

Babin, B. J. \& Babin, L. (2001). Seeking something different? A model of schema typicality, consumer affect, purchase intentions and perceived shopping value. Journal of Business Research, 54(2): 89-96.

Babin, Barry J., Darden, William R., \& Griffin, Mitch. (1994). Work and/or fun: Measuring hedonic and utilitarian shopping value. Journal of Consumer Research, 20, 644-656.

Baldus, B. J., Voorhees, C., \& Calantone, R. (2015). Online brand community engagement: Scale development and validation. Journal of Business Research, 68(5), 978-985.

Batra, R. \& Ahtola, O. (1991). Measuring the hedonic and utilitarian sources of consumer attitudes. Marketing Letters, 2(2), 159-170.

Batra, R., \& Keller, K. L. (2016). Integrating Marketing Communications: New Findings, New Lessons and New Ideas. Journal of Marketing, 80(6), 122-145.

Bhattacharya, C. B., \& Sen, S. (2003). Consumer-Company Identification: A Framework for Understanding Consumers' Relationships with Companies. Journal of Marketing, 67(2), 76-88.

Blackwell, R.D., Miniard, P.W., Engel, J.F. (2005). Consumer behaviour. New York: The Dryden Press.

Bowden, J. (2009). The process of customer engagement: A conceptual framework. Journal of Marketing Theory and Practice, 17(1), 63-74.

Brodie, R. J., Hollebeek, L. D., Jurić, B., \& Ilić, A. (2011). Customer engagement: Conceptual domain, fundamental propositions, and implications for research. Journal of Service Research, 14(3), 252-271.

Brodie, R. J., Ilic, A., Juric, B., \& Hollebeek, L. D. (2013). Consumer engagement in a virtual brand community: An exploratory analysis. Journal of Business Research, 66(1), 105-114.

Etkin, J., (2016). The hidden cost of personal quantification. Journal of Consumer Research, 42(6), 967-984.

Hirshman, E. C., \& Holbrook, M. B. (1982). Hedonic consumption: emerging concepts, methods and propositions. Journal of Marketing, 46(3), 92-101.

Hollebeek, L. D. (2011). Demystifying customer brand engagement: Exploring the loyalty nexus. Journal of Marketing Management, 27(7-8), 785-807.

Loureiro, S. M. C., Panchapakesan, P. (2017). How to Achieve Subjective Well-Being Through Medical Tourism: The Engagement Process Through Credibility, Desire, and Experience. In: Advances in Psychology Research. vol. 120.

Minor, M. S., Mowen, J. C. (2003). Consumer behaviour. New York: Pearson PrenticeHall.

Patterson, P., Yu, T. \& de Ruyter, K. (2006). Understanding customer engagement in services. Advancing theory, maintaining relevance, proceedings of ANZMAC 2006 conference, $4-6$. 
Perugini, M. \& Bagozzi, R. P. (2001). The role of desires and anticipated emotions in goal-directed behaviors: Broadening and deepening the theory of planned behavior. British Journal of Social Psichology, 40(1), 79-98.

Rokeach, M. (1973). The nature of human values. New York: The Free Press.

Schamari, J., \& Schaefers, T. (2015). Leaving the home turf: How brands can use webcare on consumer-generated platforms to increase positive consumer engagement. Journal of Interactive Marketing, 30, 20-33.

Sprott, D., Czellar, S., \& Spangenberg, E. (2009). The Importance of a General Measure of Brand Engagement on Market Behavior: Development and Validation of a Scale. Journal of Marketing Research, 46(1), 92-104.

van Doorn, J., Lemon, K. N., Mittal, V., Nass, S., Pick, D., Pirner, P., \& Verhoef, P. C. (2010). Customer Engagement Behavior: Theoretical Foundations and Research Directions. Journal of Service Research, 13(3), 253-266.

Vivek, S. D., Beatty, S. E., \& Morgan, R. M. (2012). Customer Engagement: Exploring Customer Relationships Beyond Purchase. Journal of Marketing Theory and Practice, 20(2), 122-146.

Zhang, J., Jiang, Y. X., Shabbir, R., \& Du, M. F. (2015). Building industrial brand equity by leveraging firm capabilities and co-creating value with customers. Industrial Marketing Management, 51, 47-58. 